\title{
IIICTE ILCEA
}

Revue de l'Institut des langues et cultures

d'Europe, Amérique, Afrique, Asie et Australie

44 | 2021

Peinture, identité nationale et style international en

Europe autour de 1900

\section{Imitando al artista «más español». Goya y la construcción de una identidad nacional en la pintura de género española (1868-1919)}

Imitating the "Most Spanish Artist". Goya and the Construction of a National Identity in the Spanish Genre Painting (1868-1919)

À la façon de l'artiste "le plus espagnol ». Goya et la construction d'une identité nationale dans la peinture de genre en Espagne (1868-1919)

\section{Guillermo Juberías Gracia}

\section{OpenEdition}

\section{Journals}

\section{Edición electrónica}

URL: https://journals.openedition.org/ilcea/12260

DOI: 10.4000/ilcea.12260

ISSN: 2101-0609

Editor

UGA Éditions/Université Grenoble Alpes

Edición impresa

ISBN: 978-2-37747-324-3

ISSN: $1639-6073$

\section{Referencia electrónica}

Guillermo Juberías Gracia, «Imitando al artista «más español». Goya y la construcción de una identidad nacional en la pintura de género española (1868-1919)», ILCEA [En línea], 44 | 2021,

Publicado el 02 noviembre 2021, consultado el 03 diciembre 2021. URL: http://

journals.openedition.org/ilcea/12260 ; DOI: https://doi.org/10.4000/ilcea.12260

Este documento fue generado automáticamente el 3 diciembre 2021.

(C) ILCEA 


\title{
Imitando al artista «más español». Goya y la construcción de una identidad nacional en la pintura de género española (1868-1919)
}

\author{
Imitating the "Most Spanish Artist". Goya and the Construction of a National \\ Identity in the Spanish Genre Painting (1868-1919) \\ À la façon de l'artiste "le plus espagnol ». Goya et la construction d'une identité \\ nationale dans la peinture de genre en Espagne (1868-1919)
}

Guillermo Juberías Gracia

\section{NOTA DEL AUTOR}

Este artículo ha sido realizado en el marco del grupo de investigación Observatorio Aragonés de Arte en la Esfera pública, dirigido por el catedrático Jesús Pedro Lorente y financiado con fondos FEDER por el Gobierno de Aragón.

\section{El papel de Goya en la articulación del nacionalismo cultural español}

Goya, en sus Fusilamientos, pintados en medio del horror y de la lucha, en sus caballerescos retratos, en sus escenas populares, en sus fiestas de sangre, en sus tipos trágicos - presentación la más pura de nuestra raza-, nos despide quizá para siempre de España. Grande es, pues, la representación nacional del pintor aragonés (Soriano, 1892: 1).

1 En la segunda mitad del siglo xIx, la rápida sucesión de acontecimientos políticos -la Revolución Gloriosa en 1868, la llegada al poder en 1871 de una nueva dinastía encarnada en Amadeo de Saboya, la proclamación en 1873 de la Primera República y la 
Restauración borbónica de 1874- pusieron en peligro el proyecto de construcción del Estado liberal articulado durante el reinado de Isabel II (1833-1868). Precisamente, una de las cuestiones más representativas del siglo xIX fue la gestación de los nacionalismos, fenómeno que alcanzó su auge durante el Romanticismo y que culminó con las unificaciones italiana y alemana, concluidas en 1870 y 1871 respectivamente. España no se mantuvo al margen de esta voluntad nacionalista y, al igual que en otros Estados europeos, fundamentó su propio canon histórico, literario, musical y artístico, enfatizando ciertos aspectos de la cultura nacional y relegando otros al olvido, al ser considerados expresiones locales o menos representativas del «carácter español».

2 En esta cuidadosa selección de la historia, una de las épocas más polémicas fue el reinado de Carlos IV (1788-1808) y su dramático desenlace en la Guerra de la Independencia (1808-1814), un episodio reciente de la historia nacional, releído en clave patriótica desde los discursos institucionales. A nivel artístico, Francisco de Goya -el pintor español más sobresaliente de este periodo- constituye un buen ejemplo de esa revisión idealizada de la España de finales del siglo xviI y comienzos del xIX.

3 Esta tendencia en los campos literario y artístico se aprecia a la perfección en los Episodios Nacionales de Benito Pérez Galdós, especialmente en su primera serie, publicada entre 1873 y 1875 en mitad de esa inestabilidad política. Uno de ellos se dedicó específicamente a la corte de Carlos IV, englobado dentro de esa primera serie que concluye con el desenlace de la Guerra de la Independencia. Para Galdós, este enfrentamiento bélico desencadenó el despertar de una conciencia popular nacional (Aizpuru, 2001: 818)1. Además, desde un punto de vista artístico, el escritor canario comprendió la importancia de ilustrar adecuadamente su texto escrito, encargando dibujos a reconocidos artistas españoles como los hermanos Mélida, Alejandro Ferrant, Ángel Lizcano, Carlos Pellicer o Apeles Mestres. De todos ellos Arturo Mélida fue su principal colaborador (Lara, 2001: 917-931), retratando a Goya como pintor de cámara en una ilustración de La corte de Carlos IV.

4 También en este ámbito de lo literario, es importante destacar la recuperación a finales del siglo xix de los sainetes de Ramón de la Cruz, uno de los escritores más relevantes de la época de Goya. Gracias a la fórmula del teatro por horas, el sainete dejó de ser una pieza secundaria vinculada a otra principal de mayor entidad, para ganar autonomía y ser representada como obra principal (Espín, 1995). Entre otros literatos decimonónicos, Tomás Luceño recuperó esta tradición sainetera de finales del siglo xviII, escribiendo sainetes de nueva creación como el llamado: ¿Cuántas, calentitas, cuántas?, subtitulado: Continuación de «Las castañeras picadas de don Ramón de la Cruz». Al igual que sucedió con los Episodios Nacionales, Ángel Lizcano, Apeles Mestres o Josep Llovera colaboraron en la ilustración de los sainetes en su reedición de 1882, utilizando imágenes del universo goyesco² ${ }^{2}$.

5 A nivel institucional las preocupaciones eran las mismas y así se constata en la política expositiva desarrollada por el Museo del Prado. Interesaba una visión muy condescendiente de la época de Goya, que no cuestionase a la propia dinastía borbónica y que contribuyese a su identificación con los valores de la nación. Por ello, a mediados del siglo xIX, con José de Madrazo en la dirección del museo, Los fusilamientos y La lucha con los mamelucos (1814) estaban expuestos en una galería pequeña y mal iluminada (Vega y Vidal, 2013: 341-422). Madrazo los consideraba obras secundarias, frente al Goya retratista, complaciente con la corte, con cuadros como los retratos ecuestres de Carlos IV y María Luisa, ubicados en una posición de honor. El Goya alegre, optimista y 
cortesano fue bien recibido en el Museo, y por ello, la primera sala monográfica dedicada a un pintor fue la «sala de Goya» de 1875, destinada a la exposición de los cartones para tapices, redescubiertos en 1869 por Gregorio Cruzada Villaamil en los almacenes del Palacio Real de Madrid.

6 La faceta más contestataria de Goya tardó más en ser valorada. Ejemplo de ello fueron sus Pinturas negras (1819-1823), recibidas por el Museo en 1881, no siendo hasta 1896 cuando seis de ellas fueron expuestas en la rotonda de entrada, un espacio acorde a su relevancia artística. El proyecto de exponer el conjunto tuvo lugar en 1898, momento de creación de un gran espacio dedicado a las múltiples facetas del maestro aragonés (Juberías, 2019a: 143-163). No es casual que el proyecto de esta nueva sala de Goya se encuentre datado en 1898. Esta fecha marcó un punto de inflexión en la consideración del pintor de Fuendetodos. Tras el Desastre del 98, los artistas e intelectuales españoles llevaron a cabo una profunda reflexión sobre la esencia nacional. Fue a partir de entonces cuando la vertiente más crítica y oscura del maestro aragonés fue valorada desde las instituciones, tal y como se aprecia en la instalación de las Pinturas negras en esta dependencia del Prado, al mismo nivel que el Goya cortesano ${ }^{3}$. En palabras del escritor Francisco Fernández Villegas, la sala contribuía a resucitar la España de finales del siglo XvIII:

Ciertamente, penetrar en la sala de Goya de nuestro Museo Nacional es como asistir a la resurrección momentánea de la sociedad de fines del siglo xviII y principios del siglo xix. En esa sociedad puede decirse que el personaje reinante es la maja. Ella es la protagonista de esa gran galería de cuadros creados por el genio del pintor aragonés (Fernández, 1901: 1).

7 Dos años más tarde, tuvo lugar la conocida exposición del recién creado Ministerio de Instrucción Pública y Bellas Artes, que fue dedicada monográficamente a Goya y que supuso la definitiva consolidación del artista como un referente para la plástica contemporánea española (Vega, 2002). En ella fueron expuestas numerosas obras desconocidas hasta entonces, pertenecientes a colecciones privadas y fue un auténtico homenaje patriótico orquestado desde el Estado. Ese mismo año, los restos de Goya trasladados desde Burdeos fueron inhumados en Madrid junto a los de otros ilustrados exiliados como Menéndez Valdés, Donoso Cortés y Moratín, en un panteón edificado para ellos en el cementerio de San Isidro de Madrid (Álvarez, 2013: 27-28).

8 Los homenajes a Goya continuaron durante los años siguientes, dedicándole salas monográficas en museos de diferentes ciudades españolas como la del Museo de Bellas Artes de Valencia (1910) o la del Museo Provincial de Zaragoza (1915), heredera del espacio dedicado al artista en ese mismo edificio con motivo de la Exposición HispanoFrancesa de 1908.

9 También en 1915 se hizo efectiva la compra de la casa natal de Goya en Fuendetodos, por parte de Ignacio Zuloaga, quien además promovió con su propio dinero unas escuelas anejas a dicha casa (Castán, 2016: 207-208). Cabe destacar el monumento a Goya en Fuendetodos (fig. 1) que el pintor vasco impulsó, obra del artista catalán Julio Antonio y culminado en 1920. Había sido ideado años antes, como evidencia la maqueta conservada en el Museo Nacional Centro de Arte Reina Sofía, un brillante vaciado en yeso que demuestra un cambio sustancial en la visión de Goya ${ }^{4}$. Es un busto pensado para ser contemplado desde abajo, alejado de las airosas composiciones de otros monumentos a Goya como el de José Llaneces (1890) o Mariano Benlliure (1902). En él, el maestro de Fuendetodos contempla a su público con el ceño fruncido, demostrando 
ese carácter crítico de Goya, tan apreciado desde la Generación del 98. La culminación de esta valorización de su figura fue el traslado definitivo de sus restos a la iglesia de San Antonio de la Florida, en 1919.

Fig. 1. - Inauguración del monumento a Goya, grupo de Zuloaga y sus amigos, 1920, Archivo Histórico Provincial de Zaragoza. Referencia: ES/AHPZ - MF/SIPA/_0475_021.

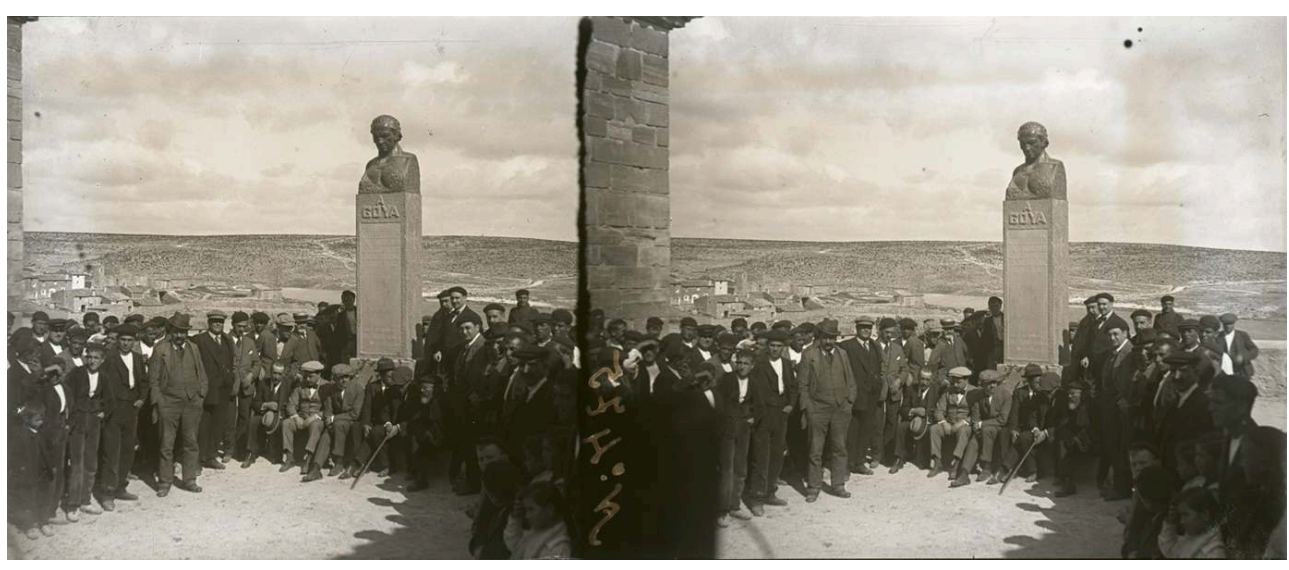

Además de las reivindicaciones por parte de pintores y escultores, otro aspecto en el que lo goyesco gozó de gran repercusión social fue en las artes del espectáculo y en el ocio cultural español de finales del siglo xix y comienzos del xx. Durante este periodo, hubo ejemplos de magníficas zarzuelas y óperas en las que la España de Carlos IV cobró vida de nuevo. En el ámbito de la zarzuela sobresalió Pan y Toros de Barbieri, estrenada en 1864 y para la que trabajó el pintor madrileño Manuel Castellano, recuperando en sus figurines referentes iconográficos de finales del siglo xVIII y comienzos del xix como los repertorios de trajes de Antonio Rodríguez Onofre o Juan de la Cruz Cano y Olmedilla (Juberías, 2019b: 287-310). Esta zarzuela inspirada en la época citada fue el punto de partida de otras muchas que, hacia finales de la centuria, utilizaron asuntos castizos.

11 Todo ello tuvo su culminación en el nacionalismo musical de Falla, Albéniz o Granados. Fruto del interés de este último por la recuperación de Goya tuvo lugar en 1919 el estreno en París de la ópera Goyescas, en la que colaboraron Ignacio Zuloaga y Maxime Dethomas en la elaboración de decorados a modo de cuadros de género de inspiración goyesca.

12 Un último campo en el que podemos constatar el desarrollo de estas tendencias goyescas fue en las fiestas de disfraces y bailes, tanto aristocráticos como populares. El universo de Goya fue frecuentemente imitado en la elaboración de trajes y, sobre todo, en la organización de los llamados "cuadros vivos», traducción del francés tableaux vivants, en los que se reproducían pinturas del maestro aragonés. La prensa española de este periodo se encuentra plagada de noticias sobre estos festejos, que también son ejemplo de la colaboración de los artistas en la organización de este tipo de espectáculos, pues a menudo los cuadros vivos eran coordinados por célebres pintores. Federico de Madrazo acudió a una de estas fiestas acompañando a su hija Cecilia y a su nieta en 1884, dejando como testimonio un bello boceto titulado María Luisa Fortuny, nieta del pintor, con traje de maja (fig. 2). Tal y como se apuntó en la prensa, hubo lugar para el cuadro vivo en este baile: «Entre estos dos grupos, allá en el fondo, copiando un tapiz de Goya, manolas y chisperos jugaban a la gallina ciega». Los asistentes se dividieron en dos grupos, aquellos que, vestidos a la manera de la corte de Carlos IV 
emulaban el «carnaval de ayer» y un grupo más variado que representaba el «carnaval de hoy» (G. J. A., 1884: 4). Este tipo de espectáculos siguió gozando de gran popularidad hasta los años 20 del siglo siguiente.

13 Frecuentemente se contó con artistas de renombre como Horacio Lengo o José Moreno Carbonero para la organización de estos cuadros vivos, y es precisamente en ese contexto de colaboración de los pintores con los literatos y los dramaturgos donde debemos comprender el auge que vivió la moda goyesca en la pintura de género española de finales del siglo XIX y comienzos del xx.

Fig. 2. - María Luisa Fortuny, nieta del pintor, con traje de maja, 1884, Federico de Madrazo. Licencia Creative Commons CCO.

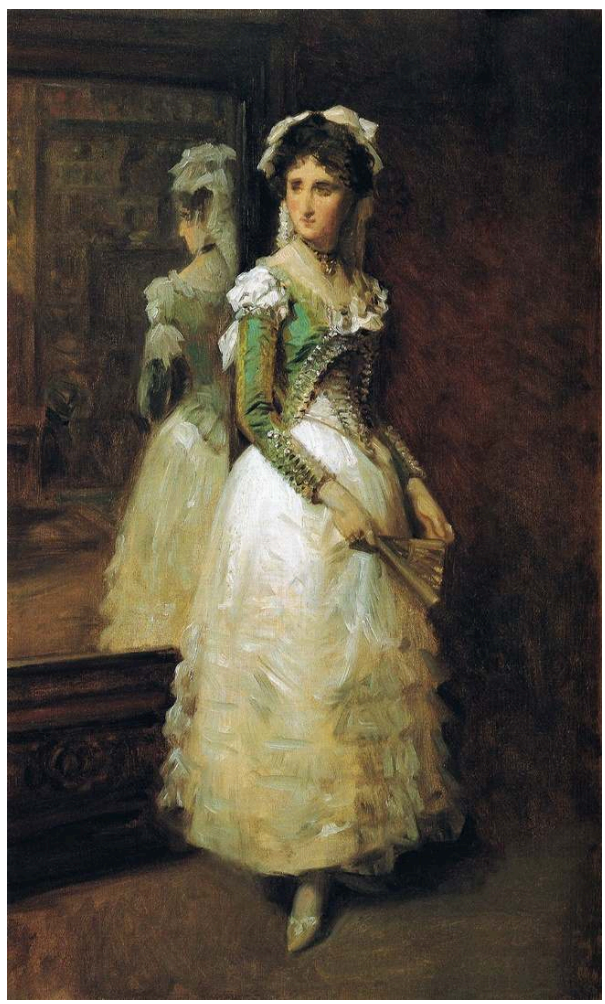

\section{Pintura de género y homogenización cultural en la España de finales del siglo XIX}

14 Hay que analizar el papel que la pintura de género tuvo en el proceso de génesis de la identidad española en la segunda mitad del siglo XIX, comprendiendo por pintura de género aquellos cuadros de asuntos anecdóticos, generalmente protagonizados por personajes anónimos en actitudes cotidianas extraídas del presente, o, como sucedió con el cuadro goyesco, inspiradas en tiempos pretéritos. En este sentido es interesante valorar su reconocimiento en los certámenes institucionales. Por Real Decreto del 28 de diciembre de 1853 quedaron instituidas en España las Exposiciones Nacionales de Bellas Artes, que funcionaron como un magnífico escaparate del arte oficial español. Aunque en sus dos primeras ediciones (1856 y 1858) las primeras medallas fuesen para obras de pintura de historia y de paisaje, en la tercera (1860) una pintura de género de Dionisio Fierros titulada Una romería a las afueras de Santiago mereció uno de estos 
galardones. En la quinta exposición (1864) se crearon premios específicos para la pintura de costumbres inspirada en el pasado -quedando desierta la medalla de primera clase- y de género, donde se alzó con la distinción el pintor francés Jules Worms por la obra Un bodegón en Asturias (Anónimo, 1864: 77). Sus pequeñas dimensiones, sus temáticas acordes a los valores y anhelos de la burguesía y su brillante colorido y factura, contribuyeron a la progresiva ascensión de la pintura de género en las muestras oficiales (Bonet, 2000: 145-156).

Sin embargo, el espacio de la pintura de género no fue el de los certámenes nacionales. Los artistas que la practicaron orientaron su producción hacia un mercado burgués, deseoso de comprar cuadritos que imitasen en su estética el arte de los maestros españoles de tiempos pretéritos. Fueron pintores que ambientaron sus obras en la España de los Austrias o en la corte de Carlos IV, practicando las escenas de género en las que representaban épocas pasadas, sin el dramatismo ni la heroicidad de la pintura de historia. El interés del género inspirado en el pasado estaba en la escena cotidiana y mundana, en la que frecuentemente los personajes son desconocidos ${ }^{5}$.

Existió una deriva doble en la pintura de género española de la segunda mitad del siglo XIX. Algunos pintores, afligidos por la temprana muerte de Fortuny en 1874, quisieron continuar la exitosa estela dejada por el maestro en la capital francesa. Creadores como Raimundo de Madrazo, Vicente Palmaroli o Ignacio León y Escosura se asentaron en París y cultivaron una pintura de género acomodada a las modas impuestas por los marchantes como Goupil. Estos artistas practicaron una estética mucho más internacional, apreciándose en ellos tendencias como la pintura inspirada en la escuela holandesa del siglo XvII, la pintura de casacón de inspiración dieciochesca o incluso el japonismo (Vottero, 2012).

Sin embargo, aquellos creadores que se dedicaron a la pintura de género desde España, no manifestaron de forma tan evidente estas tendencias y buscaron sus referentes en los grandes maestros del arte nacional: Velázquez, Ribera, Murillo o Goya ${ }^{6}$. El resultado fue el carácter genuino de esta pintura de género, alejada de las tendencias imperantes en Europa. Al igual que sucedió en el ámbito de la zarzuela o en el de la literatura, esta pintura contribuyó a la construcción de una identidad nacional española en la esfera pública, gracias a la cuidada selección de los temas. Los cuadritos fueron un reflejo del proceso de homogenización cultural que tuvo lugar en España durante la Restauración, en el que se potenció una imagen centralizada del país frente a las identidades periféricas, en auge en aquel momento (Achilés y García, 2012: 483-518).

Los asuntos abordados por esta pintura de género inspirada en el pasado fueron variados. Fundamentalmente, podemos distinguir entre las temáticas ambientadas en la época de los Austrias Menores y las que evocaban el reinado de Carlos IV. Los asuntos tratados solían ser escenas cortesanas ambientadas en los palacios y jardines reales aunque los personajes normalmente fuesen anónimos- y la captación de escenas callejeras -representaciones de las clases populares de estos siglos, llevando a cabo actividades cotidianas en mercados, en espacios religiosos o en ambientes festivos, dando especial protagonismo a las romerías y a los festejos taurinos-. En ocasiones estos asuntos poseían una inspiración literaria directa, como sucedió con la obra de Cervantes y la de Ramón de la Cruz, dos fuentes importantísimas para la pintura de género española del último tercio del xIx.

La utilización masiva de estos asuntos podría parecer inofensiva, pero, desde 1868, la pintura costumbrista española repitió hasta la saciedad la inspiración en la España de 
Goya y Carlos IV, reiterando unos tipos sociales - majas, manolas, chisperos, toreros, petimetres- que contribuyeron a la identificación de lo español con lo madrileño, atenuando otras identidades regionales que poseían un carácter propio. De esta manera, la pintura de género se convirtió en una muestra más del proceso de homogenización cultural, una tendencia común a casi todos los Estados europeos, desde finales del siglo XviII hasta la Segunda Guerra Mundial (Conversi, 2012: 437-481). En el caso español consistió, a grandes rasgos, en la reducción de la diversidad cultural existente en el territorio nacional, para reforzar y difundir valores, costumbres e imágenes asociadas al Estado centralizado, identificado con Castilla y, más en concreto, con la capital, Madrid. Una parte de la intelectualidad española de la segunda mitad del siglo XIX asumió que la verdadera esencia de la nación se encontraba en las clases populares de la época de Carlos IV, quienes reaccionaron contra lo foráneo y rechazaron la influencia de la cultura francesa frente al espíritu ilustrado de las élites (Álvarez, 2001:136). Los humildes madrileños que pueblan las obras de Ramón de la Cruz eran ejemplo de patriotismo y de ahí que fuesen recuperados por la pintura y la literatura decimonónica.

20 Este centralismo cultural sirvió para identificar a la dinastía borbónica con el patriotismo y la defensa de la nación (Fusi, 2000: 130). El madrileñismo de las majas y las manolas no sólo fue convertido en un símbolo de la resistencia frente a lo francés, sino que también fue utilizado en otros momentos de "crisis patriótica», véase la llegada al poder de la casa de Saboya con Amadeo I en 1871. Es conocido el episodio de la «rebelión de las mantillas», cuando las aristócratas de la capital salieron al Paseo del Prado ataviadas con mantillas y vestidas de manolas como rechazo de la nueva dinastía, posicionándose a favor de la vuelta al poder de los Borbones. En aquella época, la mantilla y la peineta eran elementos trasnochados, y, sin embargo, volvieron a ponerse de moda a finales del siglo XIX como expresión de un majismo renovado.

21 Paradójicamente, en el ámbito de la pintura, esta moda fue secundada por artistas de muy diversa procedencia dentro del territorio nacional. Por supuesto, los pintores madrileños fueron sus principales adalides, pero también hubo vascos, aragoneses, catalanes o andaluces dedicados a las temáticas goyescas, como se aprecia en los artistas analizados en este estudio.

22 Ya a comienzos del siglo xx hubo voces críticas que se alzaron contra la simplificación de identificar lo español con lo madrileño, llegando a criticar el alcance del madrileñismo en las costumbres. Al respecto fueron elocuentes unos artículos del periodista canario Domingo Doreste Rodríguez (1901) titulados «El madrileñismo y la prensa» publicados en el diario salmantino El Lábaro:

«Madrid y provincias» decimos para expresar el conjunto de la nación [...]. No solamente en las lindes de la política y de la administración se debe emprender el múltiple asalto a tan vano artificio, sino también en las costumbres donde se ha infiltrado el madrileñismo, suplantándolo todo.

Madrid, como gran ciudad, es solo una improvisación. Para hacer de capital absorbente no tiene otras condiciones que las que le presta el actual régimen. Por lo tanto, no puede ser bien vista su engañosa superioridad, su falsa hegemonía. Intentar que nuestra corte actúe como ciudad a lo parisién, es el colmo de lo ridículo [...]. Hora es ya de que las provincias prueben a rehacerse y a poner en su punto las mil madrileñerías con que se las emboba. (Doreste, 1901:1-2)

Para este madrileñismo simplista que criticaba Domingo Doreste en sus artículos, el principal referente artístico era el Goya cortesano y edulcorado de los cartones para 
tapices. De la variada producción del maestro aragonés expuesta en el Museo del Prado desde 1898, los cartones seguían siendo las obras más copiadas, tal y como refleja el Libro de copistas de obras de Goya, un valioso testimonio de los visitantes que acudieron al Prado entre 1898 y 1901 para reproducir obras del pintor de Fuendetodos ${ }^{7}$. También surgieron críticas a esta asimilación de lo goyesco al madrileñismo casticista, sobre todo en los prolegómenos del centenario de la muerte del artista en 1928. El escritor conservador José María Salaverría (1927) criticó muy duramente esta moda de lo goyesco entre el pueblo llano, refiriéndose a él despectivamente:

Y entre estos otros van incluidos los seres de más tremenda indigencia intelectual. Todos, por ejemplo, los aficionados a los toros; todos los que en los balnearios de tercera fila suelen improvisar una «verbena goyesca»; todos los vocales de Casino con pretensiones culturales que organizan con mucho aparato un «baile goyesco»; todas las cocineras que por el Carnaval salen vestidas de majas, o de chulas, o de cualquier cosa en una «carroza goyesca». (Salaverría, 1927: 3)

Salaverría abogaba por una puesta en valor del Goya crítico y moderno, tendencia también defendida por pintores de esta época como Gutiérrez Solana o el propio Zuloaga, quienes derivaron esta moda de lo goyesco hacia planteamientos más profundos y evolucionados, alejados del cuadro de género finisecular.

\section{La pervivencia de Goya en los pintores de género de finales del siglo XIX y comienzos del XX}

Ese interés por la obra y la vida de Francisco de Goya que tuvo lugar desde el ámbito institucional hasta el ocio cultural de la Restauración, también se tradujo en la pintura de género española. Lo goyesco fue uno de sus grandes temas en el último tercio del siglo XIX, coincidiendo con un creciente interés por Goya entre los artistas decimonónicos. El maestro aragonés era cada vez más copiado entre los pintores que acudían al Museo del Prado. Este fenómeno también se dio en la Real Academia de Bellas Artes de San Fernando, donde obras como La maja vestida (f. s. XVIII - c. s. XIX), El entierro de la sardina (1812-1819) o Corrida de toros en un pueblo (1808-1812), fueron muy reproducidas entre los artistas decimonónicos.

Así, podría estudiarse este fenómeno de la moda goyesca en la pintura de género a través de tres tipos de cuadros: las copias directas de Goya, las pinturas que incluyen citas al pintor aragonés y las obras inspiradas en la técnica y el universo goyesco.

\section{Las copias de Goya: entre el ejercicio formativo y el interés estético}

En el primer caso, se encuentran abundantes ejemplos de pintores decimonónicos que copiaron los cuadros, dibujos y grabados de Goya. Al respecto, resulta llamativa la evolución en el número de copias registradas en los libros de copistas del Museo del Prado. Si bien las obras de Velázquez y Murillo eran las más reproducidas, las de Goya vivieron un crecimiento considerable en las últimas décadas del siglo xix y las primeras del xx. Así, en 1888, tan sólo el 2,5\% de las reproducciones fueron de obras de Goya. Dicho porcentaje se duplicó hasta el 5,25\% en 1898, año en el que se decidió crear el citado libro de copistas que registró solamente las copias de Goya para el periodo comprendido entre 1898 y 1901. Dicho crecimiento alcanzó su culminación en los años 20 de la siguiente centuria, cuando las cifras de reproducción de obras de Goya 
fueron mucho más parecidas a las de Velázquez y Murillo, llegando a suponer un $17 \%$ del total de copias en $1923^{8}$.

Entre los copistas más célebres de Goya, cabe destacar caso de Mariano Fortuny (1838-1874), bien conocido por la enorme atracción que sintió hacia la obra del maestro aragonés. En una carta enviada a su amigo el pintor Tomás Moragas hacia 1867 afirmaba:

Hoy, con lo que he visto de Goya, estoy nervioso. ¡Si vieras qué cosas! Cada día voy conociendo que hay más afinidad entre lo que él buscaba y lo que busco yo. Los medios de que me sirvo son diversos. Tengo un frenesí, un furor para producir, iy quién sabe lo que seré! (Maserás, 1932: 162)

Esta pasión por Goya fue paralela a la publicación en 1858 de la monografía dedicada por Laurent Mathéron al artista en Francia, que ofrecía una visión de Goya pasado por el tamiz del Romanticismo, interesando sobre todo su faceta cortesana, optimista y taurina. Imbuido por este espíritu, Fortuny copió hacia 1867 un fragmento de La familia de Carlos IV (1800), representando a la reina María Luisa de Parma y al infante Francisco de Paula. También ejecutó una copia del retrato de Francisco Bayeu y Subías (1795). Junto a La Vicaría (1870), los tres lienzos decoraron la suntuosa residencia parisina de Adèle de Cassin, marquesa de Landolfo-Carcano. La copia de La familia de Carlos IV había ocupado un lugar privilegiado en el estudio del artista en Roma, tal y como revelan las abundantes fotografías que han llegado hasta nuestros días del espacio de trabajo del pintor. Todos los elementos que formaban parte de este estudio estaban perfectamente calculados, eran ricos objetos que demostraban el gusto coleccionista del maestro, y que a su vez le servían en su praxis, a la hora de copiar detalles. Por lo tanto, esta copia de Goya poseía una utilidad más allá de la meramente formativa, lo que motivó a Mariano Fortuny Madrazo, hijo del artista, a buscar esta obra y adquirirla entrado el siglo $\mathrm{xx}^{9}$. Se trata de una copia de monumentales dimensiones $(220 \times 100 \mathrm{~cm})$, algo inusual cuando los artistas realizaban réplicas de cuadros. Formalmente, el pintor de Reus no pretendía hacer una reproducción exacta del cuadro de Goya, sino que, a partir de la minuciosa técnica empleada por el aragonés en su obra, Fortuny simplificó los trazos. Utilizó una pincelada más briosa, de trazos mucho más rápidos. Cromáticamente intensificó el colorido de los vestidos, dando mayor contraste a las superficies y alejándose de la estética aterciopelada y pastel característica del lienzo de Goya.

Fortuny también se interesó por una faceta más sombría y moderna de Goya, copiando sus aguadas de Prisioneros encadenados (1810-1815), que pudo conocer a través del erudito oscense Valentín Carderera, quien poseía en su colección particular abundantes dibujos, aguadas y grabados del maestro aragonés (Barón, 2017: 180-187).

31 Además de Fortuny, cabe destacar el caso de otros dos artistas que copiaron tempranamente a Goya. El primero, Francisco Domingo Marqués (1842-1920), fue un pintor que manifestó la influencia del maestro de Fuendetodos en muchos de sus cuadros de género. Aunque tuvo su primera formación en Valencia, a partir del curso 1863-1864 se asentó en Madrid y continuó sus estudios en la Escuela Especial de Pintura, Escultura y Grabado dependiente de la Real Academia de Bellas Artes de San Fernando. Las visitas al Museo del Prado constituyeron un ingrediente fundamental para estudiar en vivo la pintura de los maestros de la tradición pictórica española. Además de un cuadro de Rubens, Domingo copió La lucha con los mamelucos (Fernández, 1998: 12), una curiosa elección teniendo en cuenta el escaso reconocimiento que tenía esta obra en el conjunto de la producción de Goya. Pocos años antes, en 1859, el viajero 
francés Louis Clément de Ris la situaba todavía en una oscura galería del museo (Clément de Ris, 1859:32), apuntando además su «dibujo elemental y su impactante incorrección», aunque el movimiento "es siempre capturado y devuelto con fuerza y originalidad». Posiblemente fuese esa maestría en la captación del movimiento la que llamase la atención del joven pintor valenciano.

No sólo los artistas españoles sucumbieron a la copia goyesca. El pintor y crítico hispanófilo Zacharie Astruc (1835-1907) fue un devoto admirador de la obra de Goya. Visitó España por primera vez en 1864, dejando abundantes notas manuscritas sobre las ciudades, las gentes y el rico patrimonio histórico-artístico que encontró durante su periplo. Como es sabido, dio a Manet valiosos consejos para el viaje que este emprendió en 1865. En una de sus estancias en Madrid Astruc copió La maja vestida (1800-1807), entonces expuesta en la Real Academia de Bellas Artes de San Fernando. Dicha copia figura en el inventario elaborado por el propio artista de sus creaciones «166. La duquesa de Alba (copiada de Goya) regalada a Manet» ${ }^{10}$.

Al margen del valor estético o formativo de estas copias, en ocasiones han generado graves problemas a la hora de su atribución. No es objeto de este artículo abordar esta polémica cuestión, pero sí pretendo señalar la calidad de ciertos artistas que actualmente continúan en el olvido historiográfico y cuyos nombres sólo se asocian a estos episodios de falsas atribuciones. Fue el caso del pintor manchego Ángel Lizcano Monedero (1846-1929), un artista de marcada veta goyesca, autor de copias del maestro aragonés como el retrato de la reina María Luisa en La familia de Carlos IV, El cacharrero (1778-1779) o el retrato del General Urrutia (h. 1798). La primera estuvo catalogada durante años como original de Goya en el Museo de Múnich. El conservador de las secciones de pintura española e italiana del siglo XVII y alemana del xIX en la Alte Pinakothek de Múnich, entre 1911 y 1931, fue August L. Mayer (1885-1944), gran conocedor de la obra de Goya, autor de numerosos artículos y de libros sobre el pintor. En el catálogo de la Alte Pinakothek de Múnich de 1930 este retrato de la reina María Luisa figuraba como un original de Goya. Sin embargo, Lafuente Ferrari en 1947 ya lo atribuyó a Lizcano, autoría mantenida hasta la actualidad en el museo (Lafuente, 1947: 272).

\section{La cita al artista como homenaje pictórico}

Un caso distinto es el de las citas a Goya en la pintura de género, realizadas con un sentido de homenaje al maestro. Fueron abundantes los cuadros en los que se representó al pintor de Fuendetodos, imaginando instantes de su vida cotidiana, fundamentalmente de su labor artística. Una composición repetida por varios artistas fue la de Goya pintando en su estudio, actualización del tema del artista en su estudio, muy frecuente en la pintura del siglo xix. Así, en 1864 un pintor desconocido, Vicente Sabater Puchades, participó en la Exposición Nacional de ese año con una obra titulada Goya en su estudio. Años más tarde, dos pintores costumbristas recuperarían esta temática, José Casado del Alisal (1832-1886) y Enrique Estevan y Vicente (1849-1927). Sus dos representaciones del estudio de Goya fueron reproducidas por el fotógrafo Jean Laurent ${ }^{11}$. Casado del Alisal mostró al pintor aragonés retratando a la maja vestida, introduciendo el recurso del cuadro dentro del cuadro (fig. 3). Trató de captar bien la pincelada del artista, más suelta y abocetada en la representación de la maja vestida que en el resto del cuadro. La versión de Enrique Estevan imaginó a Goya pintando La 
familia de Carlos IV (fig. 4). Incluyó a tres majas y a un guitarrista en actitud ociosa, lo que contrasta con la laboriosa figura de Goya. La versión de Casado del Alisal, además de tener un mejor sentido de la profundidad y una composición más armoniosa, resulta más intimista, concentrando la atención del espectador en el momento en el que Goya retrata a la maja. En los dos casos se representa el interior del taller del artista a la manera de los estudios decimonónicos, con grandes lienzos colgados en las paredes y un mobiliario rico y abundante, acompañado de lujosas alfombras, elementos militares y cerámicas orientales.

Fig. 3. - Goya pintando La maja vestida, José Casado del Alisal, fotografía de Jean Laurent y Minier hacia 1879 , M.N.P.

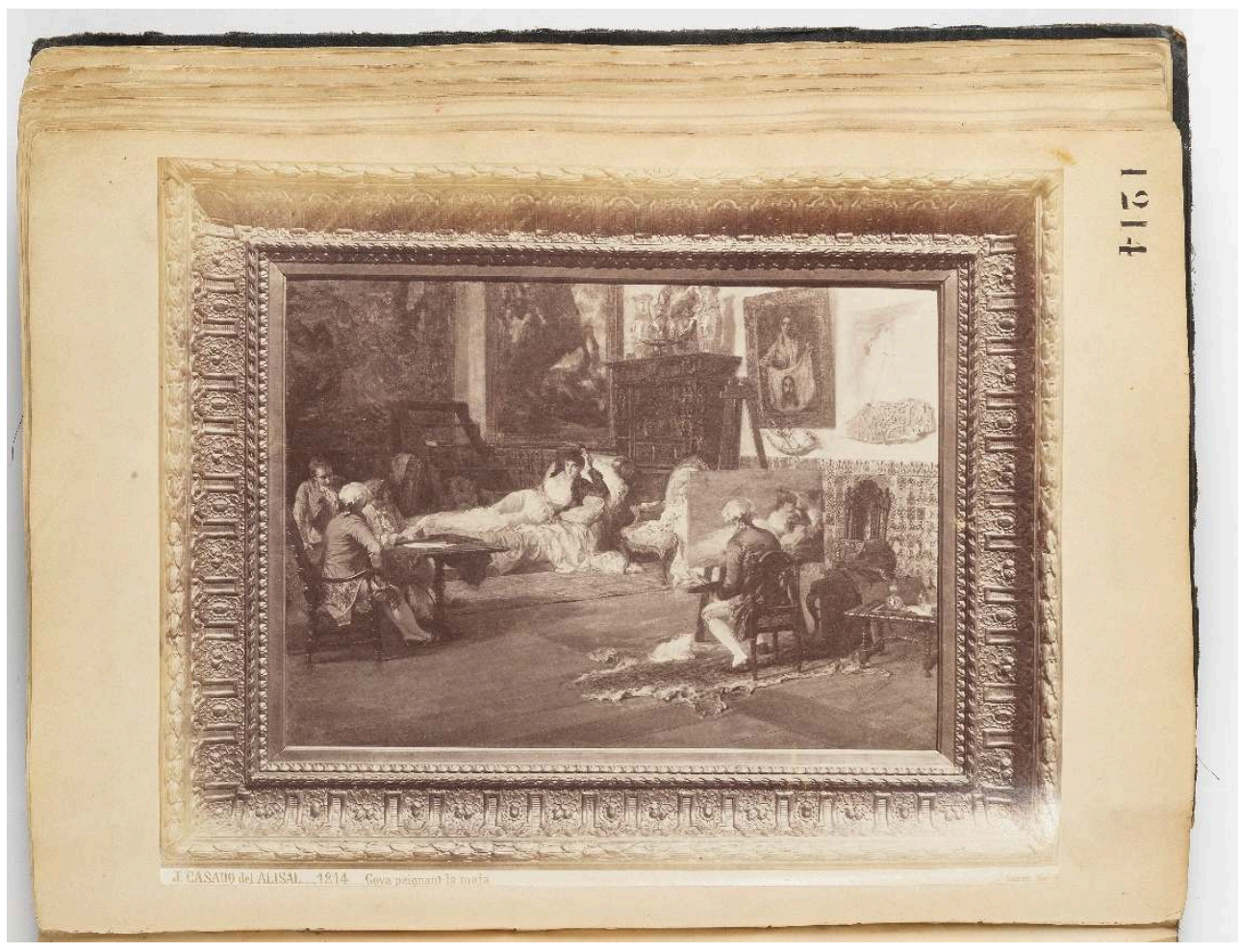


Fig. 4. - El pintor Goya en su taller, Enrique Estevan y Vicente, fotografía de Jean Laurent y Minier, 1875-1879, M.N.P.

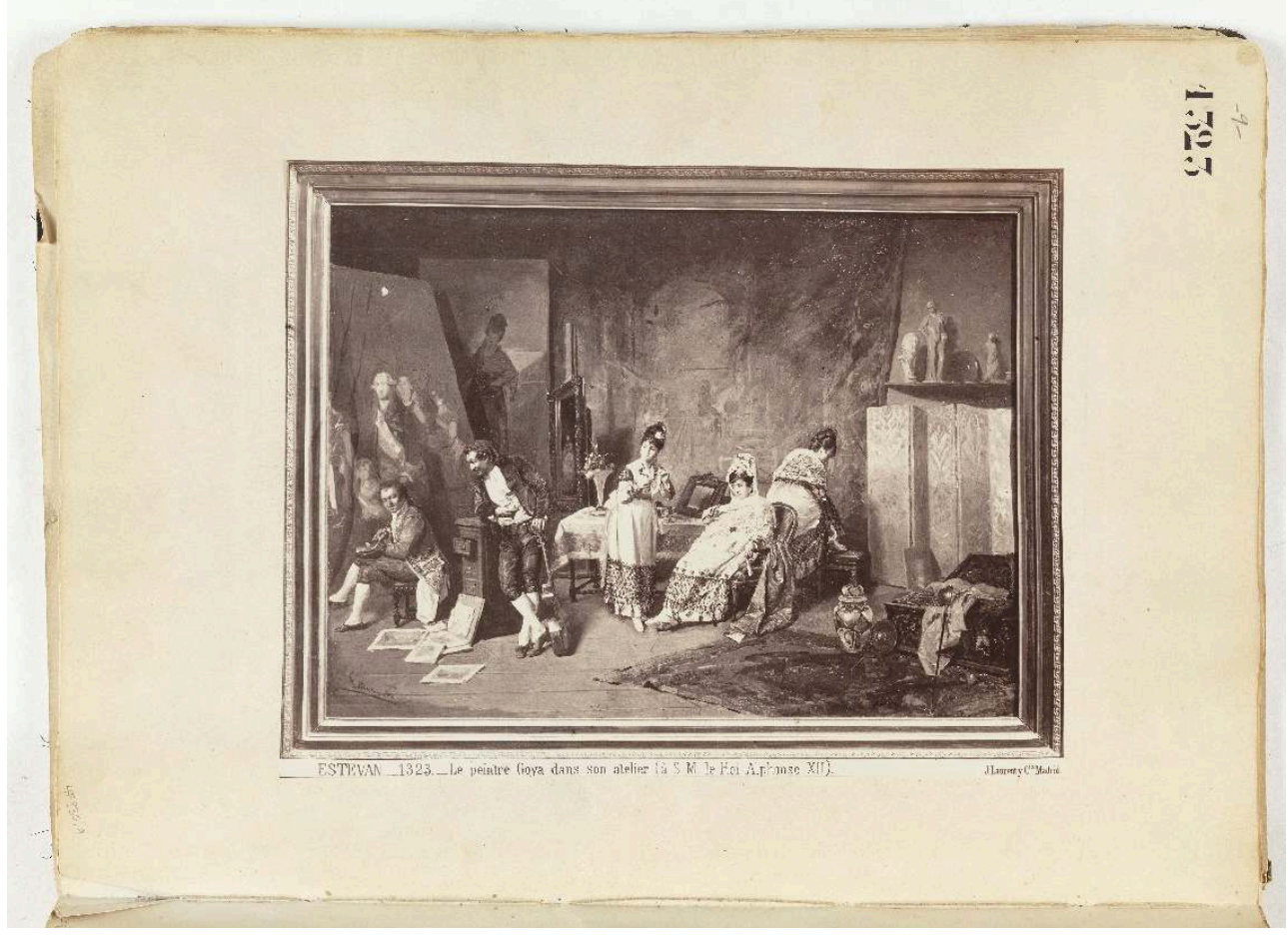

Una versión todavía más goyesca en sus tonos oscuros y su pincelada abocetada fue la ideada por el citado Francisco Domingo Marqués, autor de una pintura titulada En el estudio de Goya, reproducida en el libro Paintings and drawings by Francisco Goya in the collection of the Hispanic Society of America, editado en 1916 (Starkweather, 1916: 176). En este caso el estudio del pintor cobra un menor protagonismo, esbozándose tan sólo dos cuadros de grandes dimensiones al fondo. La atención se concentra en la figura anciana de Goya, pintando junto a un grupo de personajes en el que destacan dos majos bailando. Este detalle costumbrista contribuía a perpetrar la imagen castiza de Goya que Francisco Domingo conocía bien y que gozaba de gran predicamento en París y en Estados Unidos, dos mercados artísticos en los que el valenciano vendió buena parte de su producción.

También hubo pintores a finales del siglo xIX que sacaron a Goya de su estudio, representándolo en contacto con el pueblo madrileño. Fue el caso de Antonio Pérez Rubio (1822-1888), un pintor madrileño especializado en temáticas goyescas, autor de un cuadro titulado Moratín y Goya estudiando las costumbres del pueblo de Madrid, presentado a la Exposición Nacional de Bellas Artes de 1871 y fotografiado por Jean Laurent ${ }^{12}$. Aunque esta fotografía sea el único testimonio visual localizado, revela el carácter escasamente acabado de la obra, característica común de las pinturas de este artista tan poco investigado. En realidad, se trata de pinturas en las que se representa a Goya como un personaje más dentro del universo madrileño de finales del xVIII, relacionándose con las clases populares que había inmortalizado en su pintura. Una significación similar tuvo la obra de Ángel Lizcano Goya y Ramón de la Cruz, presenciando en San Antonio de la Florida un baile de majas y chisperos, pintada en 1887 pero difundida a través de una cromolitografía publicada en la revista Álbum Salón en 1905. 
Del resto de artistas que incluyeron citas a Goya en sus pinturas, interesa destacar el caso del pintor catalán Josep Llovera Bofill (1846-1896), otro artista que hasta hoy no ha merecido la atención de los historiadores del arte. Tal y como él mismo afirmó, sus visitas al Museo del Prado le hicieron admirar el arte de Francisco de Goya, cuya influencia es palpable en muchas de sus creaciones. Dos de ellas poseen sentido alegórico e incluyen citas al maestro aragonés, llevando por título Goya y su tiempo y Los Caprichos de Goya. La primera fue publicada por La Ilustración Española y Americana en 1885 y la segunda por La Ilustración Artística en 1896. En ambas la figura de un Goya anciano, de gesto triste, preside la composición. En torno a él aparecen multitud de personajes extraídos de sus pinturas y grabados. En la primera ilustración se distingue a Las majas en el balcón, La maja vestida, Los fusilamientos o el grabado 43 de la serie de los Caprichos: El sueño de la razón produce monstruos (fig. 5). La segunda, entre los personajes extraídos de esta serie de grabados, muestra a Goya paleta y látigo en mano, como azote de los males de la sociedad española.

Fig. 5. - Goya y su tiempo, Josep Llovera Bofill, La llustración Española y Americana, 1885.

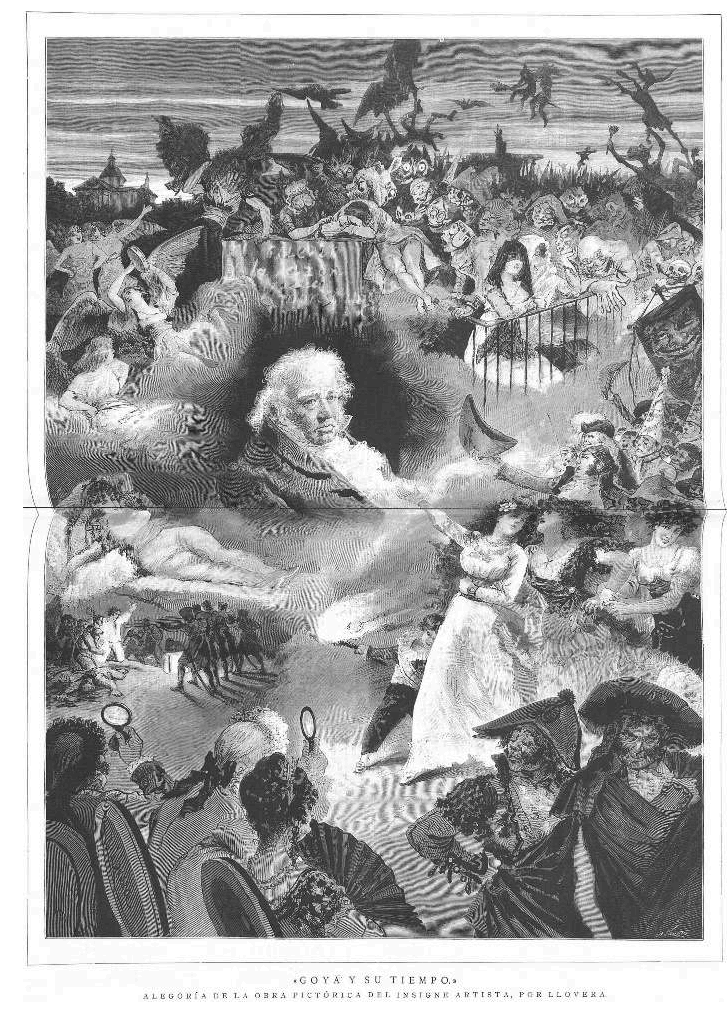

\section{El universo goyesco como fuente de inspiración temática y formal}

Por último, todo este panorama quedaría incompleto si no se trazase un breve recorrido por la obra de los artistas que manifestaron una clara influencia del arte de Goya en su producción personal. Lafuente Ferrari estableció una primera generación de pintores goyescos, integrada por artistas nacidos en vida del maestro aragonés como Leonardo Alenza (1807-1845) o Eugenio Lucas Velázquez (1817-1870). Ellos fueron los pioneros en el cultivo de las temáticas goyescas tras el fallecimiento de Goya, coincidiendo con el desarrollo del romanticismo pictórico en España. Sus obras se enmarcan en la llamada «veta brava» de la pintura madrileña, al estar caracterizadas 
por la utilización de una pincelada vigorosa y un colorido oscuro en el que predominaban los tonos ocres y pardos. Los cuadros de Alenza y Lucas explotan la faceta crítica de Goya, desarrollando una pintura en la que la deformación cobra importancia y creando una alternativa al arte académico de los Madrazo.

Siguiendo la estela de esa primera generación goyesca encontramos a otros artistas que evidenciaron la herencia del maestro aragonés. Fue el caso del gaditano Francisco Lameyer y Berenguer (1825-1877) o de los citados Antonio Pérez Rubio o Mariano Fortuny. El primero, habitualmente encasillado como un pintor orientalista, copió a Goya en los años 50 del siglo xix, en un momento en el que la figura del artista todavía no gozaba del reconocimiento que posteriormente alcanzó. El influjo de Goya sobre este artista se aprecia especialmente en una serie de grabados, poco divulgada, compuesta por seis estampas editadas por la Litografía de los Artistas hacia $1850^{13}$. La referencia a La Tauromaquia es evidente desde la primera estampa (fig. 6), para la que Lameyer se inspiró en Ligereza y atrevimiento de Juanito Apiñani en la de Madrid, el grabado 20 de la serie de Goya.

Fig. 6. - Serie de seis estampas editadas por la Litografía de los Artistas, estampa $n^{\circ} 1$, Francisco Lameyer y Berenguer, hacia 1850, B.N.E.

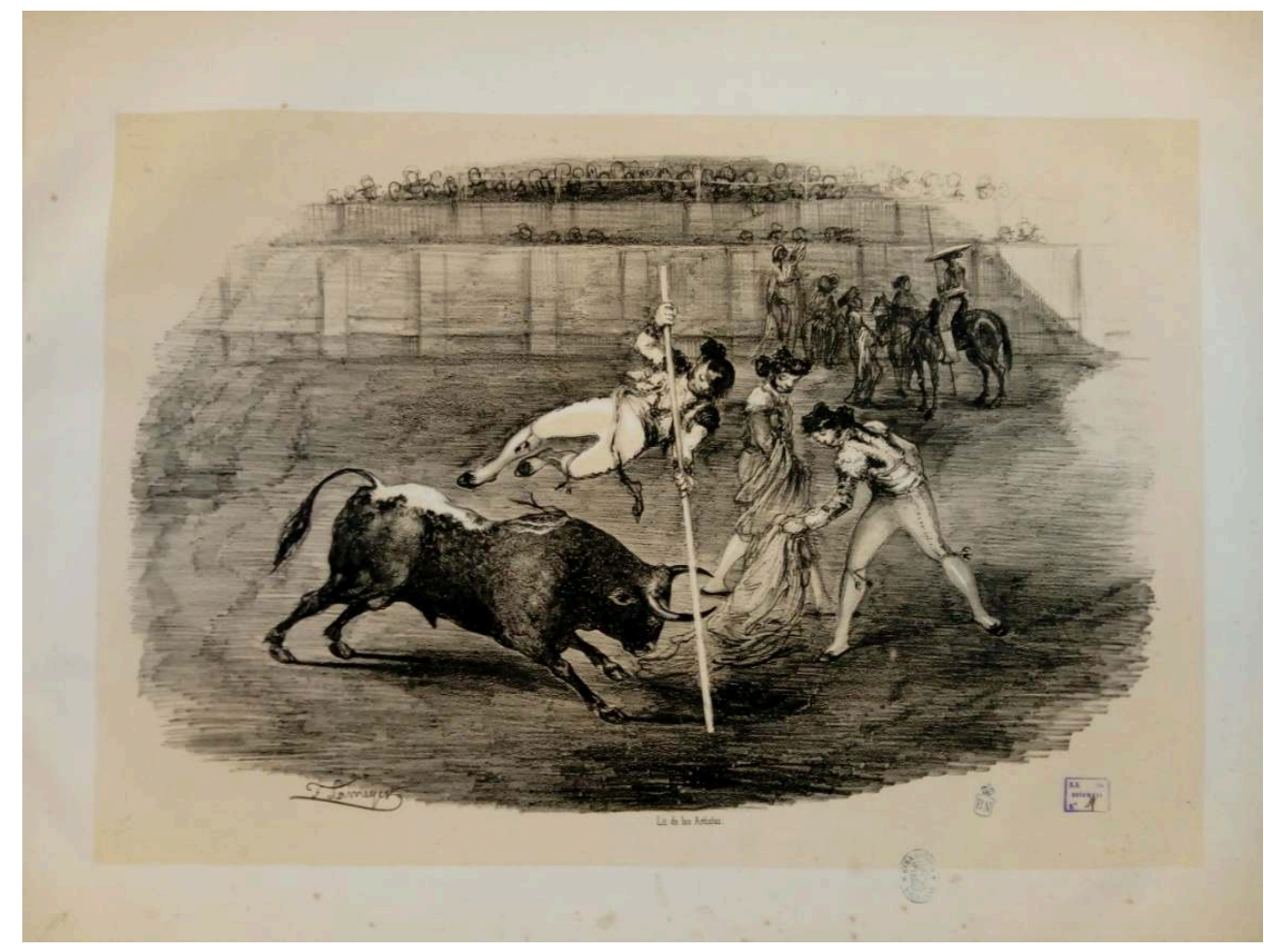

Aunque nacido tres años antes que Lameyer, Antonio Pérez Rubio manifestó su veta goyesca de manera más tardía, durante los años 70 y 80 del siglo XIX. Su admiración por el maestro le llevó a incluir citas literales en sus obras, teniendo uno de los mejores ejemplos en La aventura de Don Quijote cuando ataca a la procesión de los disciplinantes $(1882)^{14}$, en la que varias figuras están extraídas de la Procesión de disciplinantes de Goya conservada en la Real Academia de Bellas Artes de San Fernando (fig. 7). Pero además de la cita, Pérez Rubio idealizó la época de Goya, recuperando el majismo en muchos cuadritos que han acabado dispersándose tras sus ventas en el mercado del arte. 
Fig. 7. - La aventura de don Quijote, cuando ataca a la procesión de los disciplinantes, Antonio Pérez Rubio, h. 1881, M.N.P.

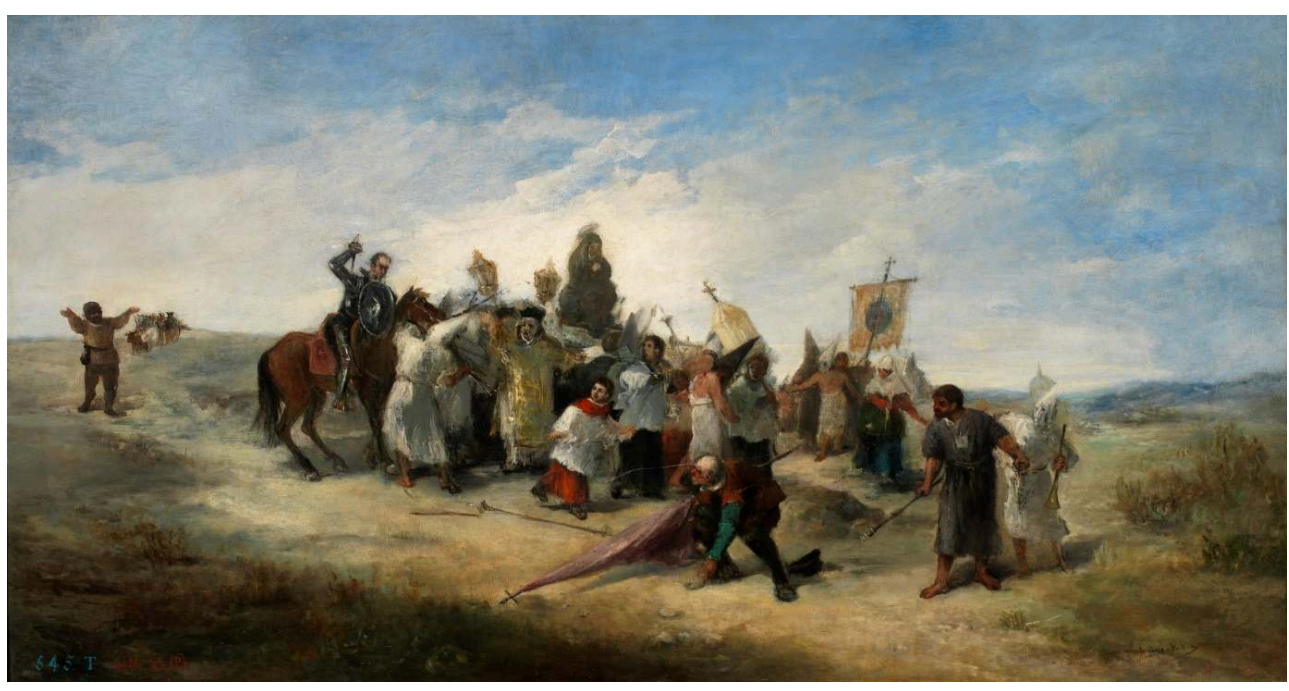

Por otra parte, además de sus copias de Goya a las que ya he aludido, Mariano Fortuny manifestó la influencia de Goya a través de sus cuadritos de inspiración dieciochesca, como la célebre Vicaría «un boceto de Goya retocado por Meissonier», según Théophile Gautier. Del mismo modo, en sus pinturas de temática taurina es evidente el estudio de Goya, en concreto de la serie de grabados de La Tauromaquia. A diferencia de la primera generación de pintores goyescos, Fortuny recondujo la influencia del maestro de Fuendetodos hacia la pintura de estética preciosista que triunfaba en el mercado internacional, ofreciendo una versión de lo goyesco más condescendiente con el gusto burgués.

También Ángel Lizcano Monedero y Josep Llovera i Bofill fueron más allá de la copia de Goya, creando obras goyescas de nuevo cuño durante los años 80 y 90 del siglo xIX. El primero presentó abundantes obras a las Exposiciones Nacionales de Bellas Artes y estudió concienzudamente la pintura de Goya expuesta en el Prado y en la Real Academia de Bellas Artes de San Fernando. Lizcano recuperó en sus pinturas el universo festivo, alegre y optimista de la España de Carlos IV, recurriendo a las mismas ambientaciones que Goya representó en sus cartones para tapices: la pradera de San Isidro, San Antonio de la Florida, etc. Una de sus mejores obras Puente de Toledo, de 1879, se conserva en el Museo de Bellas Artes de Pontevedra ${ }^{15}$. Por su parte, Josep Llovera nació en Reus y gozó de una posición económica más estable que Pérez Rubio o Lizcano, gracias a su profesión de farmacéutico. Esto le permitió dedicarse con gran libertad al arte, publicando en prestigiosas ediciones de grabados en Francia y realizando obras como La indolente, ejecutada a finales del siglo XIX y adquirida por El Círcol de Reus (fig. 8). En palabras del propio artista, se trataba de una actualización de La maja vestida de Goya. En ella Llovera llevó la referencia goyesca a una modernidad propia de comienzos del siglo xx. 
Fig. 8. - La indolente, Josep Llovera y Bofill, finales del siglo XIX, Círcol de Reus.

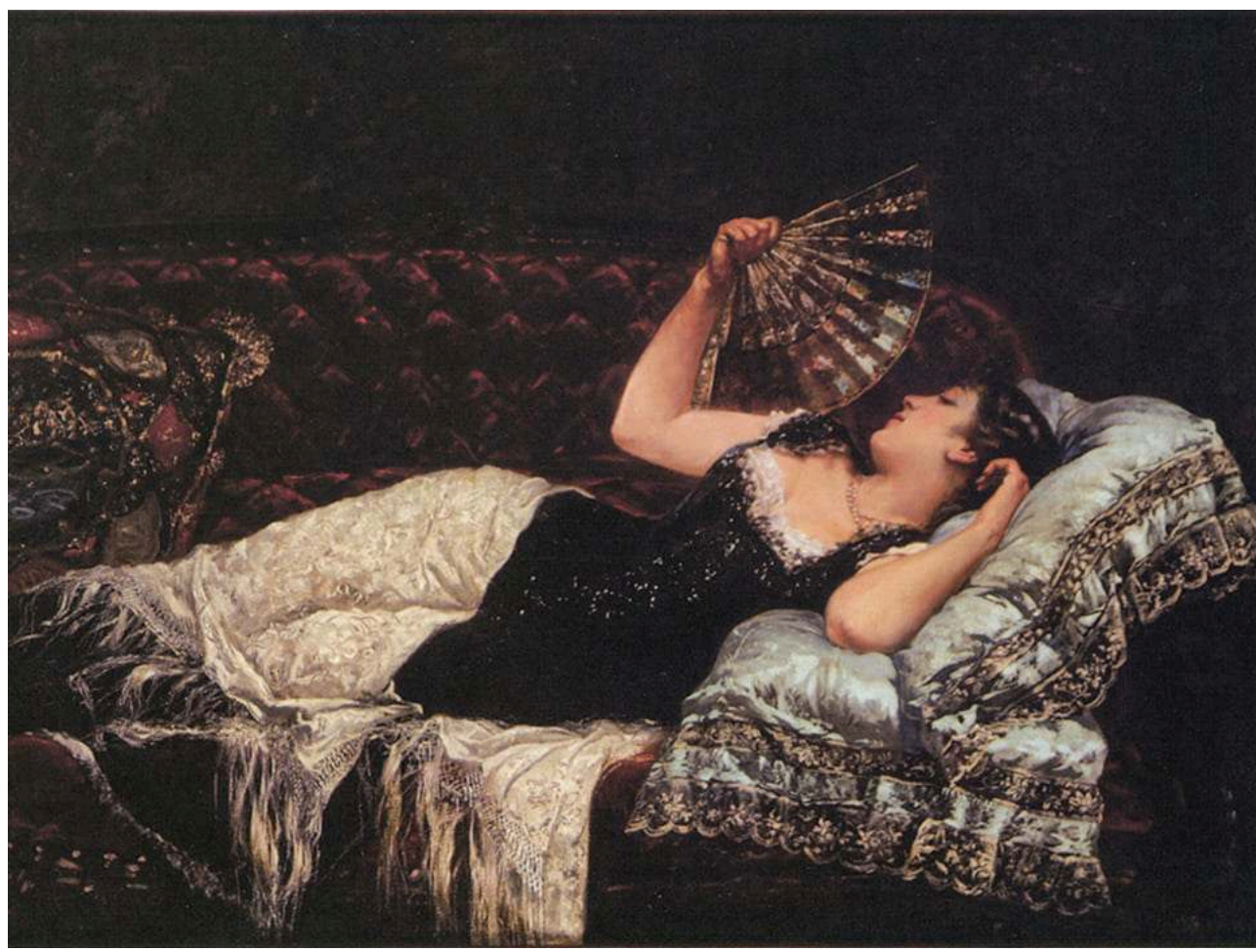

La recuperación de los asuntos goyescos no despareció a comienzos del siglo xx, al contrario, se vio revitalizada al compás de la exposición de 1900 y de las citadas iniciativas de recuperación de la figura de Goya. Sin embargo, sí es posible apreciar un cambio en la manera en que la pintura de género volvió su mirada hacia el artista aragonés. Pintores como Ignacio Zuloaga (1870-1945) o Ángel Díaz Domínguez (1879-1952) superaron el cuadrito casticista de finales del xIX, dando lugar a una interpretación mucho más profunda de lo goyesco, a partir de la apreciación del Goya más oscuro, el de las Pinturas negras. La pincelada empastada y sombría de la última etapa del pintor es muy similar a la utilizada por Zuloaga en ciertos paisajes castellanos como el presente en Mis primas (1903) ${ }^{16}$. Este conocimiento se debió a su afición coleccionista siempre pendiente de las ventas de obras del maestro aragonés. La huella de Goya se hace patente en su plástica, desde la cita a la Maja desnuda en el abanico de Doña Rosita Gutiérrez (1914-1915) ${ }^{17}$, a las reinterpretaciones de las Majas en el balcón. Zuloaga hizo uso de ese casticismo de raíz decimonónica para transmitir una renovada imagen de la tradición española, articulada en torno a la idea de esencia y de raza propia del pensamiento regeneracionista del 98. Dicha imagen no estuvo exenta de majismo, tal y como se aprecia en los decorados que junto con su cuñado Maxime Dethomas hizo para el estreno parisino de la ópera Goyescas, de Granados, en 1919. Este conocimiento se debió a su afición coleccionista siempre pendiente de las ventas de obras del maestro aragonés (Junquera, 2021: 137-150).

En esta línea trabajó el pintor riojano Ángel Díaz Domínguez, quien también citó a Goya en sus obras y aplicó a ese universo de las majas y los toreros un lenguaje más moderno. Resultan especialmente ilustrativos de esta moda sus trabajos para el Centro Mercantil, Industrial y Agrícola de Zaragoza, en cuyas pinturas se hizo especialmente patente la veta goyesca y la influencia de Zuloaga (Lorente, 2010:171). Es el caso de su pintura Inauguración de la Exposición Hispano-Francesa de 1908, o de las representaciones de majas 
ejecutadas para los salones del centro. En ellas, a pesar de perpetrar esa imagen casticista de Goya, el artista puso de manifiesto su buen conocimiento de una nueva plástica, más moderna, acorde al lenguaje del regionalismo.

Fig. 9. - Majos y majas a la orilla de un río, Ángel Díaz Domínguez, 1919, Centro Mercantil, Industrial y Agrícola de Zaragoza.

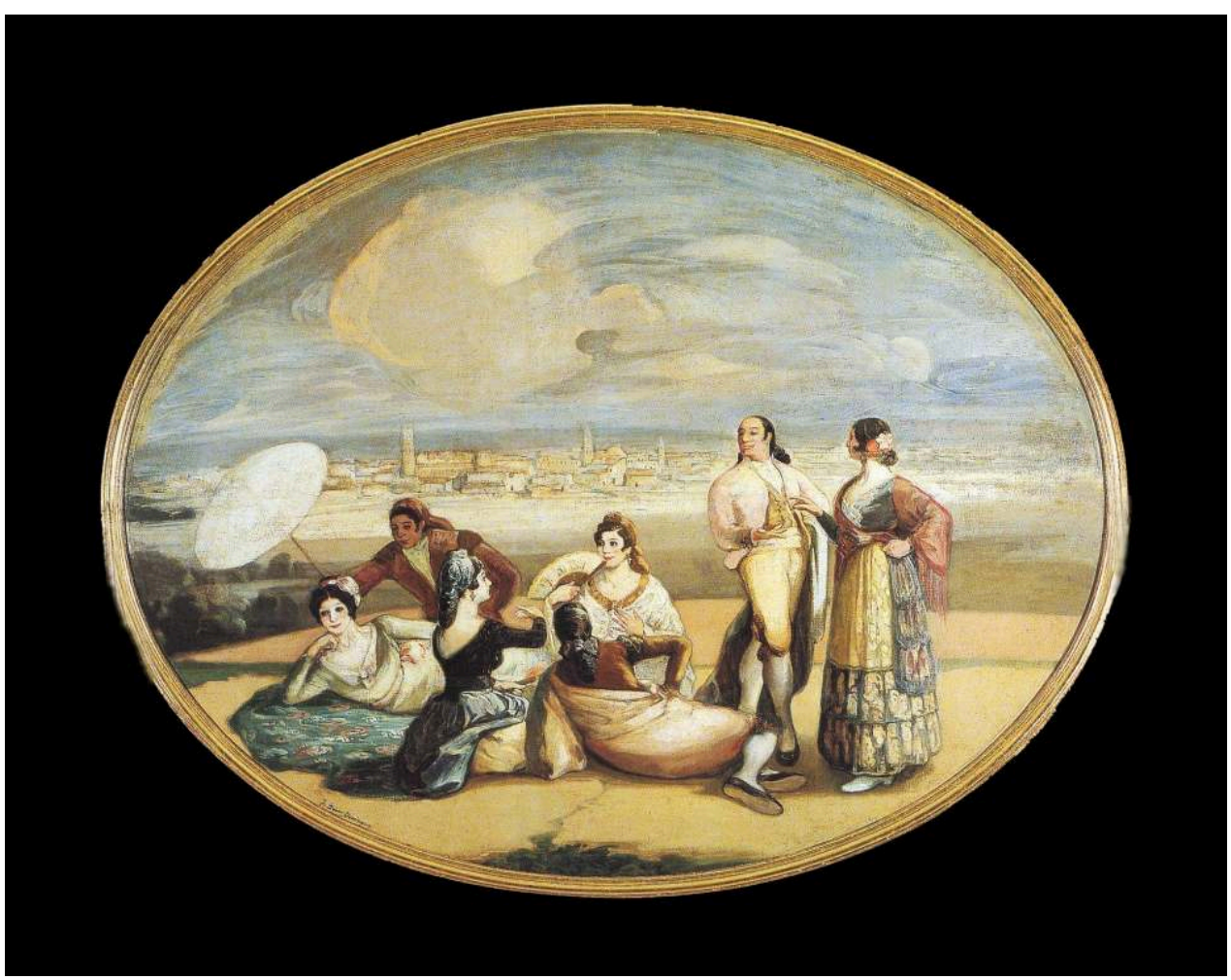

\section{Conclusiones}

La moda goyesca fue una de las más fecundas en la pintura de género española de finales del siglo xIX y comienzos del siglo xx, sin embargo, la problemática cuestión de las falsas atribuciones ha hecho que algunos de los artistas aquí investigados hayan permanecido en el olvido historiográfico hasta nuestros días. Estudiándolos, no sólo contribuimos al conocimiento de unas obras de arte escasamente valoradas, sino que también profundizamos en la investigación sobre los procesos de construcción de la identidad nacional española desde el ámbito de la pintura, comprendiendo los mecanismos de selección del pasado y de génesis de una imagen nacional concreta. A través del presente artículo ha quedado demostrado cómo el Goya de los cartones para tapices y de los retratos de corte fue un faro para los pintores españoles del último tercio del siglo XIX, teniendo que esperar hasta la exposición monográfica organizada por el Ministerio de Instrucción Pública y Bellas Artes en 1900 para que se difundiese una visión más contrastada del pintor aragonés, apareciendo artistas como Zuloaga a los que ya no sólo interesaba el Goya más castizo. Ese cambio en la valorización del pintor contribuyó a la renovación de la pintura costumbrista española en las primeras décadas del siglo xx, en la que el majismo siguió teniendo un peso considerable, pero interpretado bajo los parámetros de una mayor modernidad. 


\section{BIBLIOGRAFÍA}

AfINOGUÉNOVA Eugenia (2009), “"Painted in Spanish": The Prado Museum and the naturalization of the "Spanish School" in the Nineteenth century", Journal of Spanish Cultural Studies, 10(3), 319-340. AizPURU MURUA Mikel (2001), «Sobre la astenia del nacionalismo española a finales del siglo XIX y comienzos del XX», Historia Contemporánea (23), 811-849.

ÁLVAREZ BARRIENTOS Joaquín (2013), «Sobre la construcción de la imagen de Goya: algunos usos y abusos», Institución Fernando el Católico (dir.), Goya y su contexto (1. ${ }^{\text {ra }}$ ed.), Zaragoza: Diputación de Zaragoza, 17-38.

ÁlVAREZ Junco José (2001), Mater Dolorosa: La idea de España en el Siglo XIX (1. ${ }^{\mathrm{ra}}$ ed.), Madrid, España: Taurus.

ANÓNIMO (1864), Catálogo de la Exposición Nacional de Bellas Artes de 1864 (1. ${ }^{\mathrm{ra}}$ ed.), Madrid, España: Imprenta y Litografía del Atlas.

ARCHILÉS CARDONA Ferrán \& GARCíA CARRIón Marta (2012), «En la sombra del Estado. Esfera pública nacional y homogeneización cultural en la España de la Restauración», Historia Contemporánea (45), 483-518.

BARÓN THAIDIGSMANN Javier [comisario] (2017), Fortuny (1838-1874) [1. ${ }^{\text {ra }}$ ed.], Madrid, España: Museo Nacional del Prado.

BONET SOLVES Victoria (2000), «Construyendo una imagen, creando escuela: consideraciones sobre la pintura de género del siglo XIX en España», Ars Longa (9-10), 145-156.

CASTÁN CHOCARRo Alberto (2016), Señas de identidad. Pintura y regionalismo en Aragón (1898-1939) [1. ${ }^{\text {ra }}$ ed.], Zaragoza, España: Institución Fernando el Católico.

CLEMENT DE RIS Louis (1859), Le Musée royal de Madrid (1. ${ }^{\text {ra }}$ ed.), París, Francia: Vve J. Renouard.

CONVERSI Daniele (2012), «Nación, Estado y Cultura: por una historia política y social de la homogeneización cultural», Historia Contemporánea (45), 437-481.

DORESTE RoDRíGUEZ Domingo (1901), «El madrileñismo y la prensa. I», El Lábaro (1416), 1-2.

EsPín TEMPLADo María Pilar (1995), El teatro por horas en Madrid (1870-1910) [1. ${ }^{\text {ra }}$ ed.], Madrid, España: Instituto de Estudios Madrileños, Fundación Jacinto e Inocencio Guerrero.

FERNÁNDEZ Villegas Francisco (1901), «Crónicas de antaño-De la casa de Alba», La Época (18.518), 1.

FusI Juan Pablo (2000), España. La evolución de la identidad nacional (1. ${ }^{\text {ra }}$ ed.), Madrid, España: Temas de Hoy.

GÉAL Pierre (1999), «L'invention de l'école espagnole de peinture aux XVIII et XIX ${ }^{\mathrm{e}}$ siècles», J. C.

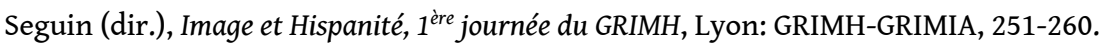

J. G. A. (1884), «Madrid», El Día (1360), 4.

JUBERÍAS GRACIA Guillermo (2019a), «Ideología y poder en los discursos museográficos: la creación de "salas de Goya" en los museos españoles (1875-1915)», Potestas (14), 143-163.

JUBERÍAS GRACIA Guillermo (2019b), «Una visión decimonónica de la España de Carlos IV: Diseños para la zarzuela Pan y Toros en las colecciones municipales de Madrid», Espacio, Tiempo y Forma, serie VII (7), 287-310. 
JUNQUERA MATO Juan José (2021), «Zuloaga y Goya. Una reflexión sobre épocas, personalidades y ambientes», I. Suárez-Zuloaga (dir.), El verdadero Ignacio Zuloaga, Madrid: Fundación Zuloaga, 137-150.

LAFUENTE FERRARI Enrique (1947), Antecedentes, coincidencias e influencias del arte de Goya (ed. 1987), Madrid, España: Sociedad Española de Amigos del Arte.

LARA GARCíA Antonio (2001), «¿Para qué sirve un libro sin dibujos? Las ilustraciones de los Episodios Nacionales», Y. Arencibia et al (dir.), Actas del séptimo congreso internacional de estudios Galdosianos, Las Palmas de Gran Canaria: Cabildo Insular de Gran Canaria.

LORENTE LORENTE Jesús Pedro (2010), «La pasión por Goya en Zuloaga y su círculo», Artigrama (25), 165-183.

MASERÁs Alfonso \& FAGES DE Climent Carles (1932), Fortuny. La mitad de una vida (1. ${ }^{\text {ra }}$ ed.), Madrid, España: Espasa Calpe.

RibAo PEREIRA Montserrat (2012), «Una relectura finisecular de los sainetes a la luz de sus ilustraciones, Los Sainetes de R. de la Cruz», R. Gutiérrez Sebastián (dir.), Literatura e imagen: La "Biblioteca Arte y Letras", Santander: Ediciones de la Universidad de Cantabria, 99-120.

SALAVERRÍA IPEnZA José María (1927), «Goya y lo goyesco», ABC (7640), 3.

SORIANO Rodrigo (1892), «Exposición de Bellas Artes. La historia de la pintura», La Época (14.429), 1.

STARKWEATHER William E. B. (1916), Paintings and drawings by Francisco Goya in the collection of the Hispanic Society of America, Nueva York, Estados Unidos: HSA.

VEGA GONZÁLEZ Jesusa [dir.] (2002), Goya 1900. Catálogo ilustrado y estudio de la exposición en el Ministerio de Instrucción Pública y Bellas Artes (1. ${ }^{\text {ra }}$ ed.), Madrid, España: Ministerio de Cultura.

VEGA GoNZÁLEZ Jesusa \& VidAL RIVA Julián (2013), «El devenir de la Historia del Arte, sus prácticas y sus consecuencias: el caso de Francisco de Goya», L. Arciniega García (dir.), Memoria y significado: uso y recepción de los vestigios del pasado, Valencia: Universitat de València, 341-422.

VOTTERO Michäel (2012), La peinture de genre en France après 1850 (1. ${ }^{\text {ra }}$ ed.), Rennes, Francia: Presses Universitaires de Rennes.

VV. AA. (1912), Catalogue des tableaux modernes, aquarelles, dessins, pastels, sculptures, tableaux anciens, dessins anciens, objets d'art \& d'ameublement, appartenant à Madame la marquise Landolfo Carcano, París, Francia: Galerie Georges Petit.

\section{NOTAS}

1. Mikel Aizpuru señala cómo «La nación española fue la gran preocupación del literato liberal. Sus obras trataban de explicar los problemas de la patria y potenciar las virtudes del carácter nacional». También apunta cómo su patriotismo no fue tan obcecado como el de otros intelectuales de su tiempo, sino que se mostró respetuoso con otros sentimientos nacionales.

2. Los sainetes de Ramón de la Cruz fueron reeditados en 1882 por la Biblioteca Arte y Letras, uno de los proyectos editoriales más importantes en la Barcelona de finales del siglo XIX, cuyas ediciones se caracterizaron por sus ilustraciones grabadas de alta calidad. Montserrat Ribao Pereira analizó la correspondencia entre los sainetes y las imágenes que los ilustran (Ribao, 2012: 99-120). 
3. Los planos de la sala se conservan en el Archivo del Museo Nacional del Prado: AMP. «Relación de los cuadros existentes en la Sala de Goya, planta y alzado de la misma y distribución de obras en sala», 1898. Caja: 1375, Legajo: 114.09, n.․ㅡㄹ: 4. Las imágenes llevadas a cabo entre 1907 y 1905 por el fotógrafo del museo, el francés Joseph Lacoste y Borde, ofrecen una visión detallada del aspecto definitivo de la sala.

4. Museo Nacional Centro de Arte Reina Sofía. Número de inventario: AD02514.

5. A diferencia de la pintura de historia, en los cuadros de género inspirados en el pasado, la atención no se dirige a la representación de episodios históricos sino a la recreación idealizada y pintoresquista de la vida cotidiana en épocas pasadas (Vottero, 2012: 79-82).

6. Todo ello coincidió con la consolidación de la noción de escuela pictórica española, un concepto que surgió en el siglo xviI y que continuó gestándose en el xIx, articulado en torno a la identificación del naturalismo como valor genuino de la pintura española, una invención que merece ser contrastada (Géal, 2001: 251-260). En este sentido, el Museo del Prado jugó un rol primordial, convirtiéndose sobre todo bajo la dirección de José (1838-1857) y Federico de Madrazo (1860-1868 y 1881-1894) en el escaparate de una nación unificada y centralizada, especialmente tras la nacionalización del museo en 1868 y su fusión en 1872 con el Museo de la Trinidad. El Prado hizo visibles para el pueblo los valores abstractos del nacionalismo (Afinoguénova, 2009: 319-340).

7. Biblioteca del Museo Nacional del Prado (B.M.N.P.). Libro de copistas de obras de Goya, 1898-1901. Sign. L39.

8. B.M.N.P., Libros de copistas, 1887-1905 (Sign. L3), 1922-1923 (Sign. L9).

9. La colección de Adèle de Cassin fue subastada en 1912 en la galería Georges-Petit de París (VV. AA., 1912). La copia de La familia de Carlos IV forma parte de la colección del Museo Fortuny de Venecia, número de inventario: FORT0242.

10. Archives Musée d'Orsay (AMO). Fonds documentaires anciens. Fonds Zacharie Astruc. Carnet de comptes, listes, et notes, p. 20. Ref. MS420 (20) 1.

11. Museo Nacional del Prado (M.N.P.). Dibujos y estampas. Números de catálogo: HF00828/089 y HF00830/009.

12. Fototeca del Patrimonio Histórico. Ministerio de Cultura, Archivo Ruiz-Vernacci. N. de inventario: VN-04381.

13. Biblioteca Nacional de España. Sala Goya. Sign. ER/1318.

14. M.N.P. N.. de catálogo: P004028.

15. Museo de Pontevedra. № de inventario: 003929.

16. Museo Nacional de Arte de Cataluña. № de inventario: 011508-000.

17. Museo de Bellas Artes de Bilbao. № de inventario: $82 / 51$.

\section{RESÚMENES}

Entre la Revolución Gloriosa y la segunda década del siglo xx, la pintura de género construyó su propio canon nacional buscando referentes en los grandes maestros de la pintura española. De todos ellos, Goya fue entendido como el artista «más español», coincidiendo con una época en la que su figura fue recuperada en conmemoraciones institucionales y particulares. De su producción interesó su faceta más cortesana y optimista, identificando a Goya con el universo madrileño de majas y manolas, transmitiendo una versión muy concreta de lo español. Así, en 
esta época en la que la cuestión de la identidad nacional era primordial, los pintores trabajaron las temáticas goyescas a través de copias, citas a Goya y cuadros en los que la influencia del maestro es palpable a nivel técnico y temático. El objetivo de este artículo es arrojar información sobre estas herencias goyescas en la pintura de género española.

Between the Spanish Glorious Revolution and the second decade of the twentieth century, genre painting built its own national canon seeking references in the great masters of Spanish painting. Among all of them, Goya was understood as the "most Spanish" artist, coinciding with an era in which his figure was recovered in institutional and private commemorations. His courteous and optimistic profile was the most followed, which led to the identification of Goya with the madrilenian universe of majas and manolas, and to the diffusion of a very concrete version of the Spanish identity. Thus, at a time when the question of national identity was paramount, painters worked on Goyesque themes through copies, quotes to Goya and paintings in which the influence of the master is palpable at a technical and themed level. The objective of this article is to set information on these goyaesque inheritances in the Spanish genre painting.

Entre la Révolution Glorieuse espagnole et la deuxième décennie $\mathrm{du} \mathrm{xx}^{\mathrm{e}}$ siècle, la peinture de genre a construit son propre canon national à la recherche de références auprès des grands maîtres de la peinture espagnole. Parmi ceux-ci, Goya a été unanimement compris comme l'artiste « le plus espagnol », ce qui a coïncidé avec une époque de reconnaissance de sa figure au travers de commémorations institutionnelles et privées. De toute sa production, c'est sa facette la plus courtoise et optimiste, identifiant Goya avec l'univers madrilène de majas et manolas, en transmettant une version très concrète de l'Espagnol, qui a intéressé le public. Ainsi, à cette époque où la question de l'identité nationale était primordiale, les peintres ont travaillé les thématiques goyesques à travers des copies, des citations de Goya et des tableaux où l'influence du maître est palpable au niveau technique et thématique. L'objectif de cet article est de fournir des informations sur ces traces goyesques dans la peinture de genre espagnole.

\section{ÍNDICE}

Keywords: genre painting, goyaesque, casticism, cultural nationalism

Palabras claves: pintura de género, goyesco, casticismo, nacionalismo cultural

Mots-clés: peinture de genre, goyesque, casticisme, nationalisme culturel

\section{AUTOR}

\section{GUILLERMO JUBERÍAS GRACIA}

Chercheur associé, département d'histoire de l'art de l'université de Saragosse guillermojuberias@unizar.es 